\title{
Discours
}

Revue de linguistique, psycholinguistique et

informatique. A journal of linguistics, psycholinguistics and computational linguistics

$3 \mid 2008$

Varia

\section{When indexicals target discursively subsidiary information: How foregrounding and backgrounding in discourse affect indexical reference}

\section{Francis Cornish}

\section{OpenEdition}

\section{Journals}

\section{Electronic version}

URL: https://journals.openedition.org/discours/6152

DOI: $10.4000 /$ discours. 6152

ISSN: 1963-1723

\section{Publisher:}

Laboratoire LATTICE, Presses universitaires de Caen

\section{Electronic reference}

Francis Cornish, "When indexicals target discursively subsidiary information: How foregrounding and backgrounding in discourse affect indexical reference", Discours [Online], 3 | 2008, Online since 23 May 2009, connection on 21 September 2021. URL: http://journals.openedition.org/discours/6152 ; DOI: https://doi.org/10.4000/discours.6152

\section{(c) (1) (9)}

Discours est mis à disposition selon les termes de la licence Creative Commons Attribution - Pas d'Utilisation Commerciale - Pas de Modification 4.0 International. 


\section{Discours n ${ }^{\circ} 3$}

\section{"When indexicals target discursively subsidiary information: How foregrounding and backgrounding in discourse affect indexical reference"}

Francis Cornish

CNRS, CLLE-ERSS, UMR 5263 and Département Études du Monde Anglophone, Université de Toulouse-Le Mirail, 5, Allée Antonio Machado, 31058 Toulouse Cedex 09

cornish@univ-tlse2.fr

\section{Résumé}

Adoptant la distinction de Berrendonner (1990 ; à paraître) entre «micro-syntaxe » et «macro-syntaxe », de même que celle, orthogonale, entre segments de discours mis au premier ou bien en arrière-plan ( $c f$. Khalil, 2005), cet article se propose d'examiner certaines interactions «non-standard » parmi ces domaines. Nous nous pencherons sur des cas où un référent potentiel est évoqué à l'intérieur d'un segment hautement présupposé, en arrière-plan discursivement, mais où ce référent est ciblé par un indexical en emploi soit « anadéictique », soit non-anaphorique, et par suite transformé en une entité de discours à part entière. Ce type de référence relève de la deixis de discours, et non de l'anaphore en tant que telle. On examinera également des segments de texte plus étendus, qui entretiennent des relations discursives en termes de « macrosyntaxe ». Nous tâcherons de caractériser les limites de la référence anaphoricodiscursive en fonction du degré de mise en arrière- ou au premier plan des unités de discours qui contribuent à déterminer l'existence du référent ainsi ciblé.

\footnotetext{
Abstract

Adopting Berrendonner's (1990; fc.) distinction between "micro-syntax" and "macrosyntax", as well as the orthogonal one between foregrounded and backgrounded discourse segments ( $c f$. Khalil, 2005), this paper aims to examine certain "noncanonical" interactions amongst these domains. In particular, I shall be looking at instances where a potential referent is evoked within a highly presupposed, discursively backgrounded text segment, but where that referent is targeted either via an "anadeictically"-used or a non-anaphorically used indexical expression and made into a discourse entity in its own right. The latter is characteristic of discourse deixis, but not of anaphora as such. I will also be looking at larger stretches of text, which relate to each other discursively in terms of "macro-syntax". I will try to characterise the limits of discourse-anaphoric reference as a function of the degree of backgrounding or foregrounding of the discourse units in terms of which that referent is determined and targeted.
} 


\section{Introduction}

1. Adopting Berrendonner's (1990; fc.) distinction between "micro-syntax" and "macro-syntax" (also termed "pragma-syntax": i.e. the lexico-grammatical as well as discourse relations spanning adjacent sentences or clauses within a text), as well as the orthogonal one between foregrounded and backgrounded discourse segments ( $c f$. Khalil, 2005), this paper aims to examine certain "non-canonical" interactions amongst these domains. In particular, I shall be looking at instances where a potential referent is evoked within a highly presupposed, discursively backgrounded textual segment in some text (for example, a restrictive relative clause, or a complement clause - both of which assume a micro-structural relation with their containing clauses), but where that referent is targeted either via an anadeictically-used indexical or via a non-anaphorically used indexical expression and (in the latter case) made into a discourse entity in its own right. The latter use is characteristic of discourse deixis, but not of anaphora as such. I shall also be looking at larger stretches of text, which relate to each other discursively in terms of "macro-syntax".

2. I will try to characterise the limits of discourse-anaphoric reference as a function of the degree of backgrounding or foregrounding of the discourse units in terms of which that referent is determined. I will begin by briefly outlining Berrendonner's distinction between the levels of "macro-" and "micro-syntax" (section 2), and will then sketch the orthogonal distinction between foregrounded and backgrounded discourse units of various sizes in terms of Khalil's (2005) account (§3). Having done this, I will differentiate in section 4 amongst discourse anaphora, anadeixis and discourse deixis. This will lead to the main focus of the paper (section 5), namely the correlations that may hold between the operation of discourse deixis, anadeixis and discourse anaphora, on the one hand, and the status of the discourse units targeted by these context-bound referring procedures as foregrounded or backgrounded units, on the other. We will see that referring via indexicals is not just a question of targeting individual referents, but involves "tying" two entire discourse units together in terms of foreground-background relations.

\section{2. "Micro-" vs. "macro-syntax"}

3. There are in fact several extant conceptions of the micro- vs. macro-syntax distinction: the Fribourg one (represented here by Berrendonner), the Aix one (research group GARS/DELIC) and the Florence school one (LABLITA research unit). See Avanzi (2007) for an illuminating comparison of these different approaches. In Berrendonner's (1990; fc.) conception, micro- and macro-syntax are types of ways in which more basic units within each domain (minimal discourse units in the case of "macro-syntax", and lexical heads, phrases and clauses in that of "micro-syntax") may be integrated into a larger, more encompassing structure. While micro-syntax is the domain of government (French "rection") by phrasal heads of their complement(s) and by groups and 
phrases of their modifiers or adjuncts, macro-syntax is the domain of coherence or rhetorical relations between discourse units, each of which may serve to augment the discourse model ("mémoire discursive") being constructed as the cotext unfolds.

4. One central test of whether a given unit is related to another in terms of micro- or macro-syntax is the possibility of felicitously using an appropriate definite lexically-headed NP to substitute a 3rd person pronoun in the second unit which is in some anaphoric relation with an antecedent expression in the first. Obviously, this test is only applicable where there exists an anaphoric 3rd person pronoun in a non-initial unit retrieving a referent evoked in the initial one. If such a substitution is possible, preserving the anaphoric relation initially established, then we may be dealing (at the level of utterance processing) with an incrementation of the discourse model under construction, and therefore with an instance of macro-syntax — though in Berrendonner's later work (Berrendonner et al., fc.), the possibility remains that other factors may still indicate that the two segments at issue are connected in terms of a micro-syntactic relation of some kind. While if this substitution is impossible, then other things being equal, the relation may be one of micro-syntax. A purely grammatically-determined (microsyntactic) relation has no such implications: it simply indicates "what goes with what", and "in what way", at the level of textualisation. ${ }^{1}$ Examples [1] and [2] below, taken from English "news-in-brief" newspaper articles, illustrate this:

\section{[1a] "US orders staff out of Uzbekistan}

The US and Israel have withdrawn [non-essential diplomatic staff and their families $\left._{i}\right]^{2}$ from Uzbekistan, after warnings that the $\mathbf{y}_{\mathbf{i}}$ could be targeted by Islamic militants. The move came after weeks of unrest in the wake of the massacre of hundreds of civilians in the town of Andijan last month." (The Guardian Weekly, June 10-16, 2005, p. 2)

[1b] The US and Israel have withdrawn [non-essential diplomatic staff and their families ${ }_{i}$ ] from Uzbekistan, after warnings that the personnel $\mathbf{~}_{\mathbf{i}}$ could be targeted by Islamic militants...

5. Replacing the 3rd person subject pronoun they in the modifying prepositional phrase introduced by after in [1a] by the definite NP the personnel, an NP capable of targeting the same referent, in [1b] is (relatively) felicitous, in that the anaphoric link realised via the pronoun they in [1a] is maintained. And indeed, the phrase is clearly only loosely connected, in grammatical terms, with the initial one. Its function is that of a sentence adverbial, providing the reason for the state

\footnotetext{
1 There is an evident (partial) parallel between Berrendonner's notion "micro-syntax" and that of text in my conception (see Cornish, 2008: Table 1, p. 998), as also between his notion "macro-syntax" and my view of discourse (see the work just cited). Micro-syntactic relations holding between syntactic units would form part of what I am calling text, which embraces the entire perceptual trace of an act of utterance. As such it includes paralinguistic features of the utterance act, as well as non-verbal semiotically relevant signals such as gaze direction, pointing and other gestures, etc. Discourse refers to the situated, revisable interpretation of utterances in conjunction with an appropriate context. Text provides the perceptible cues which, in conjunction with a relevant context, will enable the user to construct discourse.

2 In the following examples, square brackets have been inserted around textual antecedents and a subscripted letter placed before the closing square bracket, with the emboldened anaphoric expression marked with an identical subscript. This is in order to indicate the referential identity intended.
} 
of affairs evoked via the initial (main) clause. We are therefore (by hypothesis) dealing with a macro-syntactic relation here. Let us look now at example [2]:

[2a] "[Investors in the beleaguered oil firm Yukos ${ }_{\mathrm{j}}$. have been told by a Russian court that they $y_{j}$ can have no role in the organisation's bankruptcy. Analysts believe the state is attempting to renationalise the remains of the company." The Guardian Weekly, 7-13/04/06, p. 28.

[2b] \#[Investors in the beleaguered oil firm Yukos ${ }_{\mathrm{j}}$ ] have been told by a Russian court that the shareholders ${ }_{\mathrm{j}}$ can have no role in the organisation's bankruptcy...

6. In [2b] on the other hand, it would not be possible to substitute an appropriate definite NP (the shareholders) for the subject pronoun they in the governed subordinate clause introduced by that, preserving the anaphoric relation with the matrix clause subject. It is clear here, then, that the relationship between the initial predication and this subordinate clause is governed by a micro-syntactic and not a macro-syntactic relation. Another clear indication of this is the impossibility of deleting the subordinate clause in [2a]: *Investors in the beleaguered oil firm Yukos have been told by a Russian court. Compare this result with the naturalness of a deletion of the counterpart prepositional phrase in [1a]: The US and Israel have withdrawn non-essential diplomatic staff and their families from Uzbekistan. After all, the subordinate clause in [2a], unlike the counterpart PP in [1a], realises a nuclear grammatical function - that of second object of the verb told ('to tell someone something'), and is therefore a lexically governed unit.

7. The distinction may have something to do with logophoric relations: where the relation between the proposition expressed by the subordinate clause and the matrix one is such that it represents the viewpoint of a matrix clause NP's human referent (the "sujet de conscience"), then a lexical expression coreferential with it but which the intended referent would not have used in referring to himself results in a bizarre reading. In my view, this is why a 3rd person pronoun would be expected, as maintaining logophorically the sujet de conscience from the matrix clause. Three examples from Chomsky (1986: 79-80) make the point clearly (though Chomsky was concerned with a different issue in presenting them):

[3a] Reagan ${ }_{i}$ was elected, although the former actor $_{i}$ is regarded by many with a good deal of skepticism. (Chomsky's 1986 ex. (48(i)), p. 79)

[3b] Reagan ${ }_{i}$ 's main problem is that the former actor $_{i}$ is regarded by many with a good deal of skepticism. (Chomsky's 1986 ex. (48(ii)), p. 80)

[3c] $*$ Reagan $_{i}$ is aware that the former actor ${ }_{i}$ is regarded by many with a good deal of skepticism. (Chomsky's 1986 ex. (49), p. 80)

8. In [3a] and [3b], the referent 'Ronald Reagan' is being viewed from the perspective of 'many (people)', and so the lexical expression the former actor is an appropriate means of targeting this individual in the subordinate clause, maintaining that perspective; however, in [3c], the same lexical expression is 
infelicitous, ${ }^{3}$ as in the case of [2b] above, since the content of the (here lexically governed) subordinate clause is being presented from the viewpoint of 'Ronald Reagan' himself, as sujet de conscience of the entire discourse fragment. So [2b] and [3c] would both be pragmatically infelicitous for the same kind of reason: in terms of discourse, they involve crossed perspectival wires — even though in direct discourse, the reporting expression the shareholders in [2b] would correspond to a 2 nd person pronoun (you), while in [3c], it would correlate with a first-person one $(I)$.

\section{Backgrounded vs. foregrounded discourse units}

9. Background vs. foreground units may be micro-syntactic or macro-syntactic, in Berrendonner's (1990; fc.) terms. Syntactically, a given clause or phrase may be dependent with respect to a governing unit (lexeme, group or phrase), and hence represent a backgrounded unit in purely formal, syntactic (textual) terms; but at the same time, in terms of discourse it may constitute foregrounded information in relation to that evoked via what may be analysed as its governing unit in syntactic terms. An attested oral example is given in [4]:

[4] "He's pushing forty, he's developing a middle-aged spread, but Mohammed Ali has just made a bid for the heavyweight championship of the world..." (Oral utterance, $B B C$ Radio 4)

10. Here, the two initial clauses of this extract may be analysed as (paratactically connected) main clauses, syntactically, in relation to the following clause introduced by but: this clause may not occur independently of them, as a potentially main clause, initiating a discourse: *But Mohammed Ali has just made a bid for the heavyweight championship of the world - though it may when uttered in a presuppositional context of the relevant kind. Yet in terms of discourse organisation, it is clear that the central information is conveyed by this clause, for which the two paratactic initial (potentially main) clauses act as anchoring context. The connective but is thus interpreted in this context as marking a concessive and not an adversative, oppositional relation between the two units (a possible paraphrase might be "Although he may be pushing forty, and although he may be developing a middle-aged spread, Mohammed Ali has nevertheless just made a bid for the heavyweight championship of the world"). It is a "denial of expectation" use of but: there is necessarily a pause (as here) between the preceding (paratactic) clause(s) and the clause prefixed by but; and there is no requirement that the two units connected thereby be of equal rank, syntactically (as would be the case for coordinator but - cf. Kies, 1994). Notice how the presence of 3rd person pronoun (hence referentially highly dependent) subjects in the two initial main clauses, linked paratactically, reflects the discursively subordinate, background status of these units, in relation to the following clause introduced by the connective. Likewise, the presence of a full

\footnotetext{
I would prefix the example with the crosshatch rather than the asterisk Chomsky uses to characterise its status. After all, there is nothing wrong with the well-formedness of [3c] qua sentence; rather, it is the discourse to which it will give rise by default which is problematic.
} 
proper name, Mohammed Ali (a referentially-autonomous expression) in subject position, reflects the discursively foreground status of this unit. In terms of the macro- vs. micro-syntax distinction, we clearly have to do with three macrosyntactic units here, since at least the subject pronoun in the first of the two initial clauses may coherently be substituted by a definite lexical NP (e.g. the man), preserving the coreferential-anaphoric relation with the "antecedent" NP Mohammed Ali in the third.

11. In example [1a] above, the adverbial PP introduced by after is both (loosely) dependent (hence backgrounded) syntactically and subsidiary (i.e. also backgrounded) informationally - in that it serves to motivate the central situation evoked via the initial main clause. But in [2a], on the other hand, although the subordinate clause introduced by that is highly dependent (being a lexically governed unit, hence syntactically backgrounded), in terms of the organisation of the message corresponding to this text fragment as a whole, it conveys the key information. So it is a foreground, not a background unit in discourse terms. This can be brought out using Erteschik-Shir's (2007: 39, 164) so-called "lie test": if it is felicitous to contradict a given phrase or clause within an utterance, then that phrase or clause is asserted (conveys focal information in context) and is not presupposed. If the contradiction is infelicitous, on the other hand, then it corresponds to backgrounded and not to asserted information. Let us apply this test to the subordinate clause in $[2 \mathrm{a}]$ :

[2a'] [Context: A utters the first sentence of [2a], addressing B:]

B: But that's not true: they CAN ('have such a role')!

12. The result is positive, showing that the subordinate clause represents asserted, thus focused (i.e. foregrounded) and not presupposed, backgrounded information. The same test would yield a positive result when applied to [4]:

[4a] [Context: A utters [4], addressing B:]

B: That's not true! He HASn't ('just made a bid for the heavyweight championship of the world')!

13. B's contradiction here relates to the claim made in the foregrounded part of [4] (what is conveyed by the but clause). Compare this with the relatively strained objection relating only to what is conveyed by the paratactically connected main clauses:

[4a'] [Context: A utters [4], addressing B:]

B: ?\# That's not true! He ISn't ('pushing forty and developing a middleaged spread')!

14. The foreground-background distinction in discourse admits of degrees, and is not a categorical one (cf. also Givón, 1987; Khalil, 2005). Khalil suggests that it may operate in different ways at different levels, in fact. See Table 1 below: 


\begin{tabular}{|c|c|c|}
\hline Notion & Domain & Description \\
\hline Figure-Ground & $\begin{array}{l}\text { visual perception } \\
\text { cognition }\end{array}$ & $\begin{array}{l}\text { Objects are perceptually organized relative to each } \\
\text { other. }\end{array}$ \\
\hline $\begin{array}{l}\text { Grounding } \\
\text { (foreground- } \\
\text { background) } \text { structure }\end{array}$ & text semantics & $\begin{array}{l}\text { The organization of semantic representations or the } \\
\text { propositional content in terms of a grounding scale, } \\
\text { distinguishing various grounding values. }\end{array}$ \\
\hline Information structure & cognition & $\begin{array}{l}\text { One way in which knowledge is (hierarchically) } \\
\text { organized in models. It is textually constructed in } \\
\text { semantic representations, that is, meaning and its } \\
\text { organization in text. }\end{array}$ \\
\hline Prominence & text strategy & $\begin{array}{l}\text { Surface structure organization. The relative } \\
\text { conspicuousness of sentences and their constituents } \\
\text { as a result of their linear organization. }\end{array}$ \\
\hline $\begin{array}{l}\text { Foregrounding } \\
\text { backgrounding }\end{array}$ & text pragmatics & $\begin{array}{l}\text { Surface structure operations that make sentences and } \\
\text { their constituents more or less prominent and } \\
\text { influence the interpretation of text meaning in terms } \\
\text { of grounding values that have already been assigned } \\
\text { to propositions. }\end{array}$ \\
\hline
\end{tabular}

Table 1. Levels of grounding according to Khalil (2005) (Table 1 "Notions used in this study", Khalil, 2005: 3)

15. As can be seen, Khalil draws a five-way distinction amongst "figure-ground", which has to do with perception and the resulting cognition; "grounding (foreground-background) structure", which relates to text semantics ("the organization of semantic representations or the propositional content in terms of a grounding scale, distinguishing various grounding values"); information structure, which concerns how meaning is organised in texts; "prominence", determined by a given text strategy, defined as "...the relative conspicuousness of sentences and their constituents as a result of their linear organization" (p. 3); and finally, "foregrounding and backgrounding", which are bound up with text pragmatics. These are said to be "surface structure operations that make sentences and their constituents more or less prominent and influence the interpretation of text meaning in terms of grounding values that have already been assigned to propositions." The key point that seems to be at issue here is the fact that users are not "condemned" to organise their utterances in terms of the perceived "figure-ground" structure of the situation which they wish to verbalize; but that what they choose to foreground and/or to background in their message is a function of their communicative intentions.

16. The possible default grounding values are foreground, midground and background. As argued above, Khalil (2005: 4) observes that syntactic organisation does not of itself assign grounding values (e.g. syntactically subordinate clauses, as in [2a] and [4] above, do not always convey subsidiary, background information; and syntactically main clauses, as in [4], do not always

4 The distinctions between "prominence", "information structure" and "foregrounding" vs "backgrounding" are not fully clear, however - unless it is intended that part or all of an utterance becomes prominent and foregrounded (or non-prominent and backgrounded) as a result of the imposition of a given information structure upon it. In any case, we may wonder why the notion "prominence" is needed alongside "information structure", and "foregrounding" vs "backgrounding". After all, if a speaker chooses to "foreground" a discourse unit, then it will of necessity be "prominent" in terms of surface structure (i.e. lexico-grammatical realization); while if s/he elects to "background" it, then it will evidently not be prominent, surface-structurally. 
express foreground information). Grounding values are genre-specific: for example, in written news articles, the value "foreground" tends to be assigned to macro-propositions. These denote the key event or situation which the article as a whole develops. The value "background" will tend to be assigned to propositions expressing circumstantial information (the spatio-temporal setting of the main event or situation). This is what "grounds" or anchors the central information derived from the text and a suitable context. See de Vega et al. (2007) for experimental evidence in favour of the background status of preposed temporal clauses in German and Spanish introduced by the equivalents of while. Finally, the value "midground" may be attributed to propositions that elaborate or explain the main event.

17. In terms of prominence, which is a surface-structural property of texts, the point is made that what is made prominent textually may not be foreground meaning, but enjoy a relatively lower grounding value: “...prominence and importance are independent of each other" (Khalil, 2005: 6). Khalil (p. 7) goes on to write of "figure and ground slots" in text structure, which may be filled by clauses expressing background, midground or foreground propositions. Foregrounding and backgrounding are pragmatic operations with surface-structural implications, whereas foreground and background are characteristics of the semantic structure of the clauses concerned (Khalil, 2005: 11).

18. In the examples discussed so far, the background or foreground units at issue have mostly been clauses. However, when longer texts are taken into account, it is clear that each status may characterize much larger segments of text. In narrative texts, for example (see Jadir, 2005: 238-257), the foreground sequences of actions being recounted may be interrupted by background descriptions (of a scene or a character), or by a flashback or series of flashbacks to an earlier situation in which the character(s) concerned may have been involved (see examples [8] and [9] below for illustration). These interruptions often serve to explain the motivations of the characters involved at the point of interruption. Whereas the time-line of the central narration will be realised by simple past (preterit) or (historic) present tenses carried by the finite verbs involved, ${ }^{5}$ the interrupting descriptive or explanatory sequences will tend to be realised as far as tense is concerned by the past perfect (French plus-que-parfait), the simple present tense or the present or past progressive (imparfait in French). These latter types of tense/aspect (apart from the past perfect/plus-que-parfait) have as a common feature the expression of an imperfective aspect (see also Khalil, 2005: 3). However, where the shift to an earlier state of affairs is explicitly marked (e.g. via a temporal adverbial), the tense of the finite verbs in a background unit may still be the simple past, a tense type also typically used for the main time-line development in the foreground narrative units. ${ }^{6}$

\footnotetext{
5 Prototypically by the passé simple, in French. However, I do not wish to imply that this tense, or indeed the other French tenses mentioned in the text above and below, function in exactly parallel fashion with respect to their English counterparts.

6 See also Hopper (1979), Reinhart (1984), Dowty (1986), Gennari (2004) and Madden \& Zwaan (2003) on this issue.
} 


\section{Discourse anaphora, "anadeixis" and discourse deixis}

19. In my view (see Cornish, 1999, to appear), deixis and anaphora are complementary discourse-referring procedures which the user exploits in constructing, modifying and accessing the contents of mental models of an unfolding discourse represented in the minds of speaker and addressee (or writer and reader in the written form of language). Basically, deixis and anaphora are procedures for coordinating the speech participants' attention throughout the flow of text as produced within a given context to which they are both party (see in particular Clark \& Bangerter, 2004 on this issue, in terms of the act of referring more generally).

20. Both anaphora and deixis, then, operate at the level of memory organization, enabling the speaker to manage it by guiding the addressee's processing of the incoming segments of a text (cf. also Ehlich, 1982: 325, 330). Deixis under this view may be seen as involving the use of the speech situation (the (deictic) ground, in Hanks', 1992 terminology) to profile a figure (a new referent or a new conception of an existing referent within the discourse registry); while anaphora consists in the retrieval from within a given ground of an already existing 'figure', together with its 'ground', the anaphoric predication acting to extend that ground (see Kleiber 1994: Ch. 3). Examples [1], [2], [3a,b] and [4] above are illustrations: a selection of the anaphors is emboldened in these short texts. The "figure/ground" relation is thus an integral part of the operation of these two indexical referring procedures. See Cornish (to appear: section 3) for further discussion of the deixis/anaphora distinction.

21. In between the two polar types of indexicals (1st and 2 nd person pronouns, which may realize only a deictic use, on the one hand, and 3rd person reflexive pronouns, which are restricted to a (strict) anaphoric use, on the other), we find a range of expression types - mainly demonstrative-based — which may be called "anadeictic": see Ehlich (1982: 333-4) for this term. The use of one of these expression types involves partly anaphoric, and partly deictic reference. It involves the use of the basic (i.e. "situational") deictic procedure applied to the discourse already constructed (or shortly to be constructed) - hence the "anaphoric" dimension of this usage. See [10] below for an attested (written) example.

22. In the anadeictic use of demonstratives, then, there is an identifiable entity within the discourse representation upstream of the point of occurrence whose saliency level (whether low or medium) the demonstrative reference can boost. The demonstrative component may be needed here in order to differentiate the intended referent from potentially competing ones of a similar type - which a 3rd person pronoun in its place might have picked up. As Diessel (1999: 96-100) points out, anaphorically-used demonstratives tend to retrieve non-topical antecedent referents, which are less likely to be maintained unproblematically via canonical anaphor types (e.g. reduced definite NPs and 3rd person pronouns). See also Kleiber (1990) in relation to French demonstrative expressions. They are also used in the re-introduction/confirmation of macro-topical referents following 
their initial mention in a text, typically via an indefinite NP or a full proper name - this in order to firmly install the discourse representation of these discoursecentral entities in the addressee's or reader's short-term memory. They are likewise capable of inducing a topic shift. Finally, they may serve to re-activate a formerly topical referent which has since been supplanted by newly topical referents (cf. Dik's, 1997 notion "resumed topic" within his typology of topic referents).

23. Finally, discourse deixis involves contextual pointing to a part of the recently constructed discourse representation, and building it into a discourse entity which may subsequently be retrieved via an anaphor. ${ }^{7}$ In this type of contextual reference, the reader or addressee must create a referent from within the immediate discourse context. ${ }^{8}$ Clearly, it is demonstrative expressions which are specialised in this function. (See as illustration examples [5]-[7] below). The demonstrative, guided by the predicative component of the indexical clause as a whole, "points" to the relevant part of the context representation; and the process of understanding it actually creates a referent out of that representation. Unlike Piwek et al. (2008: 697), I do not believe it is just a form of "anaphora", simply because its function is to relate to prior (or subsequent) discourse. Unlike anaphora (or indeed, "anadeixis"), with discourse deixis there is no independently existing discourse entity upstream "waiting" for its reference to be picked up by a discourse-deictically used expression. Diessel (1999: 101) claims that the referent of such demonstratives "has no existence outside of the universe of discourse in the physical world." Another distinctive property of this use is the fact that the referent thereby established tends not to persist in the subsequent discourse.

24. Figure 1 below presents the various indexical referring procedures mentioned so far, in terms of a scale of indexical referring possibilities ranging from canonical deixis to canonical anaphora at each pole.

\section{canonical deixis $>$ discourse deixis $>$ anadeixis $>$ canonical anaphora}

Figure 1: Scale of indexical referring procedures

25. Examples [5] through [7] below involve a demonstrative NP or pronoun within a pragmatically foregrounded unit targeting the result of processing a text segment that forms part of a pragmatically backgrounded unit: namely, a restrictive relative clause in [5], conveying presupposed information; a presupposition associated with an indefinite NP in [6]; and an inference ("writing a musical inevitably takes a considerable amount of time") in [7].

\footnotetext{
7 See Webber (1991), Diessel (1999: 100-105), (2006: 475-6) and what Lyons (1977: 668) calls "impure textual deixis".

8 Diessel (1999: 93) characterizes discourse deixis achieved via demonstratives as "refer[ence] to propositions; they link the clause in which they are embedded to the proposition to which they refer." However, as those boring Sundays in [5] and that amount of time in [7] below, in particular, attest, discourse deixis via demonstratives is by no means limited to reference to propositions.
} 
26. To illustrate the distinction between discourse anaphora and discourse deixis, the occurrence of the demonstrative NP those boring Sundays in example [5] (lines 3-4) is particularly interesting:

[5] "There's a word for people who keep obsessive records about how often they've mowed their lawn in the past 25 years. But one listener to last year's The First Cuckoo and the Last Swallow on Radio 4 counted those boring Sundays and has now proved to be one of the many extremely important contributors to a nationwide nature diary...." ("Return of the First Cuckoo" (3.45pm R4), Radio Times 5-11.08.06, p. 132)

27. This is an example of discourse deixis in that it requires the reader to construct out of the discourse context an entity such that the people "who keep obsessive records about how often they've mowed the lawn in the past 25 years" do so once a week "on Sundays" (i.e. at the end of any given week), and that the obsessive recording of the fact is a boring, routine activity. Notice how the referent is constructed from within an informationally subsidiary textual segment (the restrictive relative clause who...years in lines 1-2 of the example) which is clearly in a micro-syntactic relation with regard to its containing NP. This corresponds to presupposed and not asserted information, and as such is backgrounded in terms of its discourse status. It is presupposed since the whole point of the NP is to evoke a stereotypical type of person - the stereotype being conveyed via the relative clause. As such, the writer assumes that there are such people, and that the reader will readily recognize their existence. As in [4], the second sentence prefaced by the conjunction But (here assuming a quasiadverbial function: see Kies, 1994) will convey the most prominent (foregrounded) information, the initial sentence as a whole then being construed as background, grounding the main information to come. The two sentences obviously contract a macro-syntactic relation with one another, in Berrendonner et al.'s (fc) terms.

28. Let us look now at a further attested, but spoken, example involving a contrastively-accented demonstrative (see Chapman, 1998 and Cornish (in preparation) on the interpretative effects of accenting in English).

$[6 a]^{9}$ [Interview with Jonathan Porritt, then leader of the environmental pressure group Friends of the Earth, by Nicholas Witchell, BBC Radio 5, 16 October, 1994]

NW: do you think that he ['Prince Charles'] will become a GREEN monarch?

JP: well, yes, but I don't think that everyone necessarily subscribes to THAT.

\section{$\mathrm{L} \quad \mathrm{L}^{*} \quad \mathrm{~L} \mathrm{H}^{*} \mathrm{~L} \%$}

NW: -- what, that he will ever one day beCOME king?

JP: yes.

(Example (2.8a) in Cornish, 1999: 30).

9 I use Pierrehumbert \& Hirschberg's (1990) notation system for intonation here, as follows: 'L' = "low pitch syllable", 'H' = "high pitch syllable"; '*’= "accented syllable”; '\%' = "boundary syllable". 
[6b]

...JP: \#...well, yes, but I don't think that everyone necessarily subSCRIBes to it

$\mathrm{L} \quad \mathrm{H} * \mathrm{~L} \quad \mathrm{~L} \mathrm{~L} \%$

[6c] Presupposition structure of the complement clause in line 1 in [6a]: "that

Prince Charles [will] become an X monarch"

Questioned predicate: "X = "environmentally-conscious"?"

Effect on this presupposition structure created by the interpretation of THAT within its predicational context: "that Prince Charles [will] become monarch"

29. In [6a], what is highlighted in the context constituted by the interviewer's initial question, given the global topic at issue, is Prince Charles' ecological credentials, not whether in fact he would ever become king one day - a proposition which is presupposed by this speaker: the prenominal adjective green was accented and pronounced with high pitch, while the head noun monarch was unaccented and carried a low level of pitch. The interviewee, however, though replying affirmatively to the question posed (Well, yes...), sought to call its presupposition into question; and he did this in part by using a strongly accented distal demonstrative pronoun (that) fulfilling a discourse-deictic function, in order to make accessible and salient an item of information which, in the context set up by the interpretation of the initial question, was in the background, not the foreground, of attention: the source of the referent evoked via construal of THAT is the governed clausal complement of think in the interviewer's first question. This is again in a micro-syntactic relation with the matrix clause; but the clause introduced by but in the interviewee's turn evidently contracts a macro-syntactic relation with the complement clause in the interviewer's first turn. I have attempted to formulate the information-structure representation of this segment of discourse under [6c].

30. In neither of the examples presented above could the retrieval have been effected felicitously via the use of a potentially anaphoric expression (for example, a reduced definite NP or a 3rd person pronoun: \#the boring Sundays or \#them in [5] and ?\#the idea/the possibility or \#it in [6]: see [6b]). Such indexicalexpression types are specialised in the expression of anaphora, where the referent retrieved is assumed to be salient for the addressee/reader to some degree - the anaphoric segment simply carrying over the situation evoked in the antecedent unit. Such units are normally retrieved from the forefront of the discourse, the backgrounded segments serving to support or "anchor" them in some way.

31. Let us look now at example [7].

[7] "I've written 14 musicals and don't have a huge desire to write another until I'm absolutely sure I want to invest that amount of time...". ( "Staging a revival", RT Interview with Andrew Lloyd-Webber, Radio Times 511/08/06, p. 18)

32. In [7], the time taken to write a musical is not in focus or even accessible when the predication I've written 14 musicals is realised. It is the result of an inference drawn at the point of interpretation of the indexical. Hence the use of a distal 
demonstrative NP that amount of time to refer to this aspect of the writing of these musicals. The demonstrative pronoun \#that or the equivalent definite lexical NP (\#the amount of time) would not have been equal to the referential task required here. Again, as in the earlier examples we have seen, the indexical reference occurs within a foregrounded segment, discursively, in relation to a referent derived from within a relatively backgrounded one, the two units arguably contracting a "macro-syntactic" relation with each other: we may analyse the initial "antecedent" clause as representing a backgrounded item of information in relation to the main, foregrounded content associated with the second conjunct ("although I've written 14 musicals, I don't have a huge desire to write another until I'm absolutely sure I want to invest that amount of time").

33. Table 2 below summarises the distinction between the anadeictic and discourse deictic uses of demonstrative expressions.

\begin{tabular}{|c|c|c|}
\hline Parameters & Canonical anadeictic use & Discourse-deictic use \\
\hline $\begin{array}{l}\text { Referent is a determinate entity } \\
\text { already bearing a minimal level } \\
\text { of saliency }\end{array}$ & + & - \\
\hline $\begin{array}{l}\text { Requires understander to } \\
\text { operate on immediate discourse } \\
\text { context, in order to construct a } \\
\text { new discourse entity }\end{array}$ & - & + \\
\hline $\begin{array}{l}\text { Possible introduction by a } \\
\text { variety of syntactic types of } \\
\text { antecedent-trigger }\end{array}$ & - & + \\
\hline $\begin{array}{l}\text { Can be replaced by a definite } \\
\mathrm{NP} \text { where denotation of NP's } \\
\text { lexical component is } \\
\text { presupposed }\end{array}$ & + & - \\
\hline $\begin{array}{l}\text { Substitutable by an unaccented } \\
3^{\text {rd }} \text { person pronoun }\end{array}$ & $+?$ & - \\
\hline $\begin{array}{l}\text { Referent likely to persist in } \\
\text { subsequent discourse (Diessel, } \\
\text { 1999) }\end{array}$ & + & - \\
\hline $\begin{array}{l}\text { Referent has no existence } \\
\text { outside the discourse, in "real" } \\
\text { world (Diessel, 1999) }\end{array}$ & - & + \\
\hline
\end{tabular}

Table 2: "Anadeictic" uses of demonstratives in English (revised version of Table 1 in Cornish, 2007: 162)

34. Sections 5 and 6 will try to identify the principles and constraints which relate anaphoric retrieval to referents associated with foregrounded discourse units, and anadeictic and discourse-deictic reference with ones to be constructed from backgrounded ones. In particular, they will aim to determine the limits of anaphoric reference within the latter type of segments. 


\section{Discourse anaphora, anadeixis and foregrounded and backgrounded discourse units}

35. Here now are two longer attested extracts (the first oral, the second written) where a subsequent reference to an already-introduced referent pops over a backgrounded segment to return to the "interrupted", main-line part of the discourse. But this is not done in the same way in each case.

36. Example [8] is an extract from an eye-witness account of the tsunami wave disaster as it affected the coast of Thailand (Patong, more particularly) in December 2004:

[8] (...) I noticed small kids and tourists walking to where the water had receded, curious as to why the water had gone. Then I saw it - I noticed people craning their necks and looking out on the horizon. You could see a wall of water about three or four stories (sic) high. I

5. felt like I was watching a movie, it was completely surreal. It wasn't moving very quickly, it took between four and five minutes until I saw it hit and in that time slowly people started to realise what was happening. People were saying 'Oh God, what is that?' I thought I was dreaming. After a few seconds the wave hit $\emptyset$ and $\emptyset$ smashed

10. against the beach. (...)

(Extract from "Eyewitness: Panic in Patong", BBC News on the Web, 27/12/04)

37. In this extract from an originally oral monologue, it is a lexical NP (the wave) and not a pronoun (it), which is used in line 9 to refer to the tsunami wave, introduced in the main-line part of the narrative preceding the brief background segment in lines 7-9. This is not due to the lack of salience in context of the intended referent (which is indeed the macro-topic at this point in the discourse). Rather, it is due to a purely discourse-structural factor: the fact that the introduction of 'the tsunami wave' by the narrator in lines 2-7 has been interrupted by his reference to the incredulous reactions of the people around him at the time (People were saying 'Oh God, what is THAT?'). This is a directspeech report, which as such momentarily shifts the locutionary source - as well as of the point of view being expressed. See also the interrupted segment in example [9] (lines 2-6) below. Note furthermore the tense difference here (preterit for the reporting segment and simple present for the reported speech segment). So in returning to the main line of narration of the sequence of events after it, there is a need to "reset the cursor" to the macro-topic and the narration of its development. Notice also that the tsunami wave has not yet been characterised as a 'wave': for the narrator uses a (mixed) metaphor in describing it in line 4 ("a wall of water about three or four storeys high" — my emphasis, FC). This need to reset the cursor is further strengthened by the fact that the direct-speech quotation just given in line 8 has stressed the difficulty the bystanders faced at the time in characterizing (categorizing, more properly) what 
they were witnessing: this is highlighted precisely by their use of the stressed distal demonstrative pronoun THAT (as also used in [6]) within an interrogative construction. In discourse terms, this reference will not yet have been ratified by the hearer or reader at this point in the text (or so the narrator assumes) - a state of affairs which calls for a lexically explicit, characterising expression type rather than a purely pronominal reference in line 9.

38. In [9] below, on the other hand, a possessive pronominal determiner and 3rd person pronoun are used following a segment which is arguably "background" (a direct speech quotation from the subject of an interview, interrupting the 3rd person report by the journalist, and illustrating the point just made prior to it), connecting up with the foreground segment preceding it. Consider the interpretation of the pronouns in the last sentence of the following extract:

[9] “...He [Kenny Rogers] grew up with four brothers and three sisters, the son of a labourer and a cleaning lady, in a poor area of Houston, Texas. "My father was an alcoholic, but it wasn't disruptive because he was a wonderful man with a great sense of humour. The worst he did for our family was use

5. money for alcohol rather than food or clothes. But he earned it, and had the right to get something out of life. He didn't drink for the last four years." His parents were not keen on him being a musician, and the early years were tough..."

(Interview with Kenny Rogers, The Radio Times, 7-13.8.99, p. 18; example (17) in Cornish, 2002).

Observe, first, that there are two discourse segments ${ }^{10}$ in this extract, an "outer" or containing segment where it is the journalist who conducted the interview who is the "locutionary source", and an inner, embedded segment corresponding to the direct speech section, where it is the interviewee, Kenny Rogers, who takes on the role of locutionary source. So this example is similar to example [8] above. The direct-speech segment is explicitly delimited graphically via the opening and closing of the inverted commas, and via the switch from third-person to firstperson pronouns in reference to the interviewee. But there are no differences as far as tense/aspect is concerned (unlike in example [8]). Note also that the local discourse topics of each segment are distinct: for the main discourse segment, this is 'Kenny Rogers', whereas for the embedded discourse segment, it is 'Kenny Rogers' father'.

39. Once the direct-speech segment is finished, it is "popped" from the highest position in the "focus stack" (according to Grosz \& Sidner's 1986 hierarchy of "focus spaces" associated with given discourse segments), and its contents are therefore no longer available for anaphors (here the possessive determiner his and the third-person pronoun him in the final sentence) to pick up. And this corresponds to intuition, since these two anaphors are unambiguous in referring

\footnotetext{
10 That is, basic discourse units, defined in part by their implementing a particular discourse purpose or goal relative to some more global discourse purpose: see Grosz \& Sidner (1986) for both the term discourse segment and its definition and illustration.
} 
to Kenny Rogers, rather than to Kenny Rogers' father, the topic of the intervening direct-speech segment. These anaphors, in conjunction with the content of their host predicator and the closing of the inverted commas at the end of the immediately preceding sentence, effect a "return pop" to the main, interrupted segment, which is about Kenny Rogers himself - even though they are in this instance 3rd person pronominal and not lexical anaphors, unlike the situation in [8]. The reason is that the popped-over segment is felt as an interruption, whereby the popped-back-to segment is continued by the popping segment. It is thus still in an active state, discursively speaking. Unlike example [8], the popped-back-to referent is already firmly installed in the addressee's mind at the point of return (and categorised as an entity of a particular type), and is no longer under construction.

40. And yet in [9], the "interruption" corresponding to the direct-speech quotation from the interviewee about his father is complex in terms of rhetorical structure and does not contain any explicit reference to Kenny Rogers (apart from the purely deictic - use of 1 st person forms my and our in the reported part). These are the two constraints imposed by Fox (1987) on return pops by same-gender pronouns (as here) to a hierarchically dominant segment.

41. [8] and [9] both involved "popping" references after a background segment to the foreground segment which "embeds" it, hierarchically. In [10] and [11] below, on the other hand, we have an anadeictic reference in [10] and an attempted anaphoric one in [11] to a referent previously evoked within a highly backgrounded segment, micro-syntactically connected to its governing one.

\section{[10] "Asia}

\section{Pakistan quake toll tops 73,000}

The death toll from Pakistan's earthquake soared to more than 73,000 and could still rise, according to official government figures. These are lower than those of other agencies, which estimate up to 87,000 dead. More than 3 million have been left homeless across Kashmir and North Western Frontier province." (The Guardian Weekly 11-17 November, 2005, p. 2).

42. In [10], the proximal demonstrative pronoun these, subject of the second sentence, refers anadeictically to 'the official Pakistani government figures (73,000 as of 11th November 2005) on the death toll from Pakistan's then recent earthquake'. This referent has just been evoked via a peripheral expression, the adjunct PP according to official (Pakistani) government figures in the initial sentence of the text. This is a sentence modifier/adjunct specifying the source of the claim made by the journalist in the main part of this initial sentence; as such, it occupies a backgrounded slot, under Khalil's (2005) account. Indeed, this referent could not have been retrieved felicitously via a canonically anaphoric expression (here \#they), since it is not in focus at the point of occurrence. This is why a proximal demonstrative pronoun was used to retrieve it, "anadeictically". Let us compare now what happens when an ordinary 3rd person pronoun is used to retrieve a referent of this kind:

\section{[11] "Militants want cleric freed}


A militant Palestinian splinter group, the Islamic Army, has demanded that Britain release a Muslim cleric in return for the freedom of BBC reporter Alan Johnston. He was kidnapped on March 12." (The Guardian Weekly, $18 / 05 / 07$, p. 2)

43. In [11], we find a very similar situation -in terms of the utterance context of the indexical. Here, the 3rd person masculine singular human-denoting pronoun he, signalling canonical anaphora, is used to retrieve a referent introduced in a peripheral phrase within the initial sentence, the adjunct $\mathrm{PP}$ in return for the freedom of BBC reporter Alan Johnston. Note that there could be a comma (or a pause in the spoken version) between the words cleric and in here, showing that this adjunct may be a sentence modifier. This is analogous to the situation prevailing in example [11], where an anadeictic, not a canonical anaphoric, expression was used to this end.

44. In fact, my feeling is that this use of he is infelicitous in this context. A more natural retrieval of this referent would have been via a reduced definite roledenoting NP, such as the journalist. In addition, the use of he results in anaphoric ambiguity here (at least at the point where the pronoun he is encountered), since the macro-topic entity in this text is the Muslim cleric (not identified by name) whose release is demanded by the Palestinian splinter group, the Islamic army. Indeed, the cleric is mentioned in the very title, which highlights the essential point of the text as a whole. Moreover, this referent is introduced in the body of the text via an indefinite NP in direct object position within a complement clause, a grammatical function higher in the hierarchy of grammatical functions than the adjunct PP introducing the second male referent. However, once the predicative component of the anaphoric sentence is taken into account, only the BBC reporter may be said to have been "kidnapped"; for the Muslim cleric is presupposed to be held in custody by Britain at the time of publication. So there is a conflict here between the import of 'top-down' and of 'bottom-up' contextual information.

\section{Conclusions}

45. First of all, our examples and discussion have shown, I think, contra what is argued in Unger (2006), that discourse is not a purely linear, "river-like" phenomenon, which "flows" along incrementally (though this may well be an accurate characterisation of "text" in any context of use: see Cornish, 2008: Table 1, p. 998). There is a hierarchical structure to it, formed by segments assuming a foreground, midground or background relation with respect to other co-occurring segments; these segments may also be related paratactically, as "sister" units assuming the same "grounding" relation with respect to some other, dominating segment (see Walker, 1998 on this point). The functioning of different types of indexicals in relation to entities evoked within these segments amply attests to this, as we have seen. For example, if an indexical expression refers in terms of a text segment which conveys presupposed information in relation to the host (anaphor-containing) segment, and the two segments contract a macro-syntactic relation with each other, then in order to achieve the reference intended, an 
expression realizing either anadeixis or discourse deixis must be used. In the former case, the referent will already be constructed and its discourse representation established in the prior discourse context; but in the latter, the referent has to be formed out of the relevant discourse context, in terms of what is predicated of this created referent. The use of a demonstrative-based expression together with its predicative context thus results in this referent not only coming into (discourse) existence, but being made salient and thus susceptible of being picked up again by a purely anaphoric expression. Table 2 in section 4 summarises the distinction.

46. Examples [5]-[7] involved background segments which are in a micro-syntactic relation with regard to their containing clauses, in Berrendonner's (1990; fc.) terms, though the indexical-containing units are in a macro-structural one with regard to these segments as whole units; and the backgrounded segments in [8] and [9] are clearly in a macro-syntactic relation with respect to the more central discourse segments within which they occur. In [8] and [9], there is no subsequent reference within the "return-popping" (foreground) segment following the backgrounded one to an entity evoked within the latter.

47. Where a canonical discourse-anaphoric expression is used (typically a 3rd person pronoun), the referent must, as in the anadeictic case, be established as a salient entity in the context discourse representation; and correspondingly, it must also have been evoked within a foregrounded (or midgrounded) text segment, in Khalil's (2005) terms (compare examples [10] and [11] in this regard, in particular) - unless the initial evocation and the anaphoric one both occur within a micro-syntactic sequence, in Berrendonner's conception. Here, it is perfectly possible (indeed expected) for the retrieval to occur within a backgrounded segment —a status which usually corresponds to micro-syntactically related segments. Reduced definite NPs may be used felicitously both in the "anadeictic" and the discourse-anaphoric situations, though not in the "discourse deictic" one.

\begin{abstract}
Acknowledgement: This paper is the revised text of a presentation entitled "Microsyntax, macro-syntax, foregrounding and backgrounding in discourse: When indexicals target discursively subsidiary information", given at the international conference DG 2008: "Illocutionary force, information structure and subordination: Between discourse and grammar" held on 23-24 May 2008 at Universiteit Gent, Belgium. I am grateful to Alain Berrendonner and Esam Khalil for reading earlier drafts of sections 2 and 3, respectively, as well as to two anonymous referees for their helpful comments on the version submitted to the journal.
\end{abstract}

\title{
REFERENCES
}

AVAnzi M. 2007. Regards croisés sur la notion de macro-syntaxe. Travaux Neuchâtelois de Linguistique 49: 39-58.

BerRendonner, A. 1990. Pour une macro-syntaxe. Travaux de Linguistique 21: 2536.

Berrendonner, A., Apotheloz, D., Beguelin, M-J., Benetti, L., Zay, F. (fc). Ch. 3: Les clauses: délimitation syntaxique. Grammaire de la période. Paris: Champion.

Chapman, S. 1998. Accent in Context. Bern: Peter Lang. 
CHOMSKY, N. 1986. Knowledge of Language. New York: Praeger.

Clark, H.H., BANGerter, A. 2004. Ch. 2: Changing ideas about reference. I.A. Noveck, D. SPerber (eds.), Experimental Pragmatics. Basingstoke: Palgrave Macmillan: 25-49.

CORNISH, F. 1999. Anaphora, Discourse and Understanding. Evidence from English and French. Oxford: Clarendon Press.

CORNISH, F. 2002. Anaphora: Lexico-textual structure, or means for utterance integration within a discourse? A critique of the Functional Grammar account. Linguistics 40 (3): 469-493.

CORNISH, F. 2007. English demonstratives: Discourse deixis and anaphora. A discourse-pragmatic account. R.A. NILSON, N. ABA APPIAH AMFO, K. BORTHEN (eds.), Interpreting Utterances: Pragmatics and its Interfaces. Essays in honour of Thorstein Fretheim. Oslo: Novus Press: 147-166.

CORNISH, F. 2008. How indexicals function in texts: Discourse, text, and one neoGricean account of indexical reference. Journal of Pragmatics 40(6): 997-1018.

CoRnish, F. (To appear - Autumn 2010). Anaphora: Text-based or discoursedependent? Functionalist vs. formalist accounts. Functions of Language, 17.2.

CORNISH, F. (In preparation). How contrastively- and weakly-stressed indexicals refer: Prosody, discourse deixis and anaphora in English.

DIESSEL, H. 1999. Demonstratives. Form, function, and grammaticalization. Amsterdam: Benjamins.

DIESSEL, H. 2006. Demonstratives, joint attention, and the emergence of grammar. Cognitive Linguistics 17(4): 463-489.

DIK, S.C. 1997. Ch. 13 in The Theory of Functional Grammar Part I: The structure of the clause (ed. K. HENGEVELD). Berlin: Mouton de Gruyter: 309-338.

DowTY, D. R. 1986. The effects of aspectual class on the temporal structure of discourse: Semantics or pragmatics? Linguistics and Philosophy 9: 37-61.

EHLICH, K. 1982. Anaphora and deixis: Same, similar, or different? JARVELLA, KLEIN (eds.): 315-338.

ERTESCHIK-SHIR, N. 2007. Information Structure. The syntax-discourse interface. Oxford: Oxford University Press.

Fox, B.A. 1987. Discourse Structure and Anaphora: Written and conversational English. Cambridge: Cambridge University Press.

GENNARI, S.P. 2004. Temporal references and temporal relations in sentence comprehension. Journal of Experimental Psychology: Learning, Memory and Cognition 30(4): 877-890.

GiVón, T. 1987. Beyond foreground and background. R.S. ToMLIN (ed.), Coherence and Grounding in Discourse. TSL vol 11: Amsterdam/Philadelphia: John Benjamins: 175-188.

Grosz, B.J., SidNER, C.L. 1986. Attention, intentions, and the structure of discourse. Computational Linguistics 12: 175-204.

Hanks, W. F. 1992. The indexical ground of deictic reference. A. Duranti, C. Goodwin (eds.), Rethinking Context: Language as an Interactive Phenomenon. Cambridge: Cambridge University Press: 43-76. 
HoPPER, P. 1979. Aspect and foregrounding in discourse. T. GIVÓN (ed.), Syntax and Semantics Vol. 12: Discourse and Syntax. New York: Academic Press: 213241.

JADIR, M. 2005. La cohérence du discours en Grammaire Fonctionnelle. Le cas du texte narratif. Rabat: Bouregreg.

Jarvella, R.J., Klein, W. (eds.), 1982. Speech, Place and Action. Studies in deixis and related topics. Chichester: John Wiley.

KHALIL, E.N. 2005. Grounding: Between figure-ground and foregroundingbackgrounding. Annual Review of Cognitive Linguistics 3: 1-21.

KIES, D. 1994. Adverbial but. The Twentieth LACUS Forum 1993. Lake Buff, IL: Jupiter Press: 315-332.

Kleiber, G. 1990. Sur l'anaphore démonstrative. M. Charolles, S. Fisher, J. JAYEZ (eds.), Le discours. Représentations et interpretations. Nancy: Presses Universitaires de Nancy: 243-263.

KLEIBER, G. 1994. Anaphores et pronoms. Louvain-la-Neuve: Duculot.

Lyons, J. 1977. Ch. 15: Deixis, space and time. Semantics,Vol 2. Cambridge: Cambridge University Press: 636-724.

MAdDEN, C.J., ZwAAn, R.A. 2003. How does verb aspect constrain event representations? Memory and Cognition 31(5): 663-672.

PIERREHUMBERT, J., HIRSCHBERG, J. 1990. The meaning of intonational contours in the interpretation of discourse. P.R. Cohen, J. Morgan, M.E. Pollack (eds.), Intentions in Communication. Cambridge, Mass.: MIT Press: 271-311.

Piwek, P., Beun, R-J., Cremers, A. 2008. 'Proximal' and 'distal' in language and cognition: Evidence from deictic demonstratives in Dutch. Journal of Pragmatics 40: 694-718.

REINHART, T. 1984. Principles of gestalt perception in the temporal organization of narrative texts. Linguistics 22: 779-809.

UnGER, C. 2006. Ch.4. Global coherence and grounding in discourse. Genre, Relevance and Global Coherence. The pragmatics of discourse type. Basingstoke: Palgrave Macmillan: 72-103.

DE VEGA, M., RINCK, M., DíAZ, J.M., LÉON, I. 2007. Figure and ground in temporal sentences: The role of the adverbs when and while. Discourse Processes 43(1): $1-23$.

WALKER, M.A. 1998. Centering, anaphora resolution, and discourse structure. Ch. 19 in M.A. Walker, A.K. Joshi, E.F. Prince (eds.), Centering Theory in Discourse. Oxford: Clarendon Press: 401-435.

WebBer, B-L. 1991. Structure and ostension in the interpretation of discourse deixis. Language and Cognitive Processes 6(2): 107-135. 